\title{
"Why is Gender a Form of Diversity?": Rising Advantages for Women in Global Indian Law Firms
}

\author{
SWETHAA BALLAKRISHNEN*
}

INTRODUCTION

Following market liberalization in 1991, the Indian legal profession has had more demands for cross-national legal services than ever

\begin{abstract}
* Swethaa Ballakrishnen is a doctorate candidate at the Sociology Department at Stanford University and an affiliate research fellow at the Program of the Legal Profession in Harvard Law School. Her research broadly investigates organizational innovation, stratification, and global influence in emerging markets. This piece is from preliminary findings of her doctoral research that inspects comparative advantages within the Indian legal profession for women lawyers. A more detailed analysis of the socio-legal institutional implications of these data is available with the Harvard Globalization Lawyers and Emerging Economies (GLEE) project. Her current projects on the legal profession include an attrition study on lawyers from large law firms, a law school survey to understand the supply side dynamics better, and a study on prestige within legal process outsourcing firms (forthcoming in the International Journal of the Legal Profession). Please forward all correspondence to swethaa@stanford.edu. The field findings for this research were made possible in large part by the Juan Celaya grant from the Onati Institute for the Sociology of Law, which covered all 2012 data collection expenses. Equally important to this project were the comments and reactions received from colleagues and participants at the International Sociological Association Meeting in Dharamsala, India (2011); the Law and Society Meeting in Honolulu, HI in June 2012 (and the LSA IRC Travel Award that allowed me to present these findings); and the International Sociological Association's Bi-Annual Meeting in Buenos Aires, Argentina in August 2012 (and the Stanford Sociology Travel Award that made attending that conference possible). Many thanks to Steve Barley, Shelly Correll, John Flood, Marc Galanter, David Grusky, Tomas Jiminez, Angela Meville, Woody Powell, Nicholas Robinson, Suryapratim Roy, Becky Sandefur, Carole Silver, Hilary Sommerlad, Ulrike Shultz, and David Wilkins for reading drafts, offering advice, and influencing framing of this paper at different stages of presentation and reflection. I am also deeply grateful to my colleagues in Stanford's Qualitative Methods Workshop, WIDER Workshop, and Inequality Workshop for comments and reactions that have helped set the tone for the broader questions this research addresses and sets up to address better in subsequent projects.
\end{abstract}

Indiana Journal of Global Legal Studies Vol. 20, Issue 2 (2013)

(c) Indiana University Maurer School of Law 
before. ${ }^{1}$ One of the ways in which the country has responded to this new work and clientele is by reorganizing its professional spaces in new, competitive ways. On the one hand, there has been a burgeoning of new, elite law schools that train young lawyers in comparative, cross-national law and include rigorous clinical curriculum. ${ }^{2}$ At the same time, there have emerged, especially over the last decade, a hoard of new legal organizations that deal primarily with transactional corporate work for large global and domestic corporate clients. ${ }^{3}$ These big law firms have

1. In 1991, the government shifted to a more open economic policy that included, predominantly, a greater involvement of the private sector and the first move toward codified foreign direct investment. For a 10-year review of the implications of these reforms on the country's economic policy, see the seminal text by India's former Finance Minister on the subject, Montek S. Ahluwalia, Economic Reforms in India Since 1991: Has Gradualism Worked?, 16 J. ECON. PERSP. 67 (2002). For analysis of the impact this liberalization has had on the legal profession and law firms in particular, see the recent work of Jayanth Krishnan that chronicles the history of law firms and legal organizations following the 1991 reforms. Krishnan, following his ethnographic research with different parts of the Indian Bar, throws light on how corporate law firms in India "have garnered great attention from domestic and international clients, academics and media . . liberalization has enhanced the powers of these lawyers already at the higher end of the pyramid." Jayanth K. Krishnan, Peel-Off Lawyers: Legal Professionals in India's Corporate Law Firm Sector, 9 Socio-Legal ReV., Sept. 24, 2013, at 4, available at http://ssrn.com/abstract=2151529.

2. While clinical education within law schools is, in itself, not a way of training lawyers for large corporate law firm practice, it speaks to the ways in which Indian law schools have recently begun to reorganize in ways that recognize the value of international standards and curriculum following the globalization of the economic markets in 1991. This has, of course, not historically been the case. See, broadly, on the need for India to borrow from but not replicate this "global" education, Frank S. Bloch \& M. R. K. Prasad, Institutionalizing a Social Justice Mission for Clinical Legal Education: Cross-National Currents from India and the United States, 13 CLINICAL L. REV. 165, 172 (2006), where Block and Prasad talk about India's inability to historically borrow from Western models of professional organization. Other prominent scholars on the global legal profession, like John Flood, have heralded India's more recent efforts in legal education (especially the setting up of these new schools) as the "most dynamic experiments in legal education." See John A. Flood, Legal Education in the Global Context: Challenges from Globalization, Technology and Changes in Government Regulation, LEGAL SERVICES BOARD, http://www.legalservicesboard.org.uk/news_publications/latest_news/pdf/lsb_legal _education_report_flood.pdf (last visited Sept. 21, 2013).

3. See Krishnan, supra note 1, at 13-14. Krishnan shows, using data from the British based consultancy group RSG, that twenty-three of the top forty firms in the country were established post 1991 (eighteen of which were established post-2000). While Krishnan does not note this, many of the other firms in the list of "Top 40" were local law practices that reorganized quite dramatically in the years following liberalization. While the oldest firm, Amarchand Mangaldas was indeed established in 1917, few would argue that its current organization and style is anything like the small, partner-founder-and-family run practice it was in the years leading to liberalization. 
expanded and grown institutionally in many unprecedented ways, ${ }^{4}$ but a striking feature of their emergence-even in the largest and most prestigious firms in the country-has been the growth and success of their women lawyers. For instance, last year, Amarchand Mangaldas, the largest and, arguably, the most influential of these big law firms, ${ }^{5}$ promoted thirteen senior associates to partnership, 70 percent of whom were women. ${ }^{6}$ In a similar vein, the other leading firm, AZB and Partners, co-founded by Zia Mody (the country's leading mergers and acquisitions (M\&A) expert who was recently cited on the Forbes list of Asia's Fifty Power Businesswomen $)^{7}$ has a gender composition of "about 50 percent," with women rising in partnership tracks with more regularity than ever. ${ }^{8}$ A large part of this explanation is that a majority of women-and associates in general-who work in these firms are graduates from the country's premiere national law schools,${ }^{9}$ which

4. Earlier reports on the Indian legal profession, for example, talk about the prototype of the Indian lawyer as more of a litigating courtroom advocate rather than a business lawyer working within the confines of a firm. See, e.g., Marc Galanter, Introduction: The Study of the Indian Legal Profession, 3 LAW \& Soc'Y REV. 201 (1968).

5. See Forbes India's review of Amarchand's place in the legal profession hierarchy in India, Shloka Nath, India's Biggest In Law, Amarchand Mangaldas, ForBES INDIA (Jul. 26, 2010), http://forbesindia.com/article/boardroom/indias-biggest-in-law-amarchand-mang aldas/15382/1. This seems to be a fairly established marker of the status of the firm. See also, for example, rankings by RSG India, Top 40 Indian Law Firms, RSG INDIA, http://rsg-india.com/rankings (last visited Jul. 14, 2013), a market overview by Legal500 for the India region, Legal Market Overview, THE LEGAL 500, http://www.legal500.com /c/india/legal-market-overview (last visited Jul. 14, 2013), and Deepali Gupta, The Five Fundamental Differences Between India's Top Two Corporate Law Firms Amarchand \& Mangaldas and AZB Partners, The ECONOMIC Times (Mar. 15, 2013), http://articles. economictimes.indiatimes.com/2012-03-15/news/31197164_1_azb-partners-zia-mody-shard ul.

6. Kian Ganz, Amarchand Promotes 13 Partners, 70\% Women, in Boon to Corporate, Comp, Lit, LEGALLY INDIA (May 2012), http://www.legallyindia.com/201205052795/Law-firms/amarchand-promotes-13-partners70-women-in-boon-to-corporate-comp-lit.

7. Asia's 50 Power Businesswomen, ForBes (Feb. 29, 2012), http://www.forbes.com/ lists/2012/13/power-women-asia-12_Zia-Mody_CVWX.html.

8. Interview with Senior Equity Partner, AZB \& Partners, Mumbai (June 18 2012).

9. For a broad review of these national law schools, see Swethaa Ballakrishnen, Where Do We Come From? Where Do We Go? An Inquiry Into The Students And Systems Of Legal Education In India, 7 J. Commonwealth L. \& Legal Prof. 133 (2009). Specifically on academic rigor and the new academic environment in these schools, see $i d$. at 148-9. For a historic review of the institutionalization and emergence of these National Law Schools, see Jayanth Krishnan, Professor Kingsfield Goes To Delhi: American Academics, The Ford Foundation, And The Development Of Legal Education In India, 46 AM. J. LEGAL HIST. 447 (2005). Krishnan suggests that while the conceptualization of an elite school that would train lawyers was not recent, it was not until the National Law Schools were incorporated in the early 1990s that legal education was institutionalized as a setting of academic rigor in that it had "improved quality and teaching methods, full 
select incoming students using highly-competitive entrance examinations, ${ }^{10}$ graduating as many women as men from their rigorous five-year undergraduate curriculum. But it is not only overarching numbers that make this emergence of potentially gender egalitarian workspaces promising. Preliminary interviews suggest that women in these big law firms ${ }^{11}$ are not discriminated against or disadvantaged as compared to their male peers in that they receive similar organizational rewards (pay, promotion, client attention) and interactional status among clients, peers and superiors alike. This is an intriguing finding in that it does not correspond to mostly gender-disadvantageous accounts of women in high status professions universally, ${ }^{12}$ nor in the legal

time faculty interested in scholarly publishing and a well-furnished library," which were all considerations that were missing in earlier avatars of Indian law schools. Id. at 462 . Similarly, other scholars of the global legal profession, like John Flood, have called India's National Law Schools "some of the most dynamic experiments in global legal education." See Flood, supra note 2.

10. The Common Law Admission Test (CLAT) is an all-India entrance test conducted by fourteen National Law Universities for admission into five-year integrated undergraduate and post-graduate degree programs. For more information, see COMMON LAW ADMISSION TEST (CLAT)-2013, http://www.clat.ac.in (last visited Mar. 1, 2013).

11. Amarchand has 555 lawyers with twenty-five equity partners and seventy-five salaried partners; AZB has 235 lawyers, with thirty-five partners and seventeen equity partners. Deepall Gupta, The Five Fundamental Differences Between India's Top Two Corporate Law Firms Amarchand \& Mangaldas and AZB Partners, ECON. TIMES, (Mar. 15, 2012), http://articles.economic times.indiatimes.com/2012-03-15/news/31197164_1_azbpartners-zia-mody-shardul. It might not seem like these are "Big" law firms the same way they seem in the West, but India's partnership laws had limitations on the size of the firm until very recently. The Indian Partnership Act, 1932, limits the number of partners to twenty, and most firms with more than twenty partners follow a multi-tiered partnership structure. The Indian Partnership Act, No. 9 of 1932, The UnrePEaled GenERAL ACtS (1933), vol. 9. The recent Limited Liability Partnership Bill (LLP Bill) in 2008 introduced the system of limited liability partnerships with no upper limit on the number of partners, but most big law firms still resort to being organized by the Partnership Act. The Limited Liability Partnership Act, No. 6 of 2009, GAZETTE OF INDIA (2009), no. 7.

12. There is little review literature on women in high status professions globally, but from independent accounts of gender segregation within high status workspaces more broadly, we know that, although feminization of high status workforces is on the rise, women have steep barriers to entry and advancement in professions like finance, stock-brokering, and consulting. For instance, Louise Roth shows in her study on women in Wall Street firms that, controlling for background characteristics, human capital, and segregation by area, women still are disadvantaged in earnings as compared to their male peers. See Louise Marie Roth, Selling Women Short: A Research Note On Gender Differences In Compensation On Wall Street, 82 Soc. FoRCES 783, 794 (2003). Other scholars that study women in finance have attributed these disadvantages resulting from work/life balance and discrimination to their entering cohort. See Mary F. Blair Loy, Career Patterns of Executive Women in Finance: An Optimal Matching Analysis, 104 AM. J. Soc. 1346 (1999). On a similar analysis of profession-specific gender disadvantages faced by women in stock-brokerages, see Janice Fanning Madden, Performance-Support 
profession specifically. ${ }^{13}$ What is more, these interviews suggest that women lawyers in these firms-and in other senior positions in firms like this-are almost oblivious to the possibility of their gender being salient in their workspace. ${ }^{14}$ In a more specific context, we know from contemporary comparative research that the Indian legal profession is more resistant to feminization than its global counterparts, ${ }^{15}$ and even exaggerated Bar Council of India Admission figures suggest than only about 10 percent of India's legal population (estimated at about 1.3 million) are women. ${ }^{16}$ It is within this framework of hostility for equal

Bias and the Gender Pay Gap among Stockbrokers, 26 GENDER \& SOC’Y 488 (2012). See also Catherine J. Turco, Cultural Foundations of Tokenism Evidence from the Leveraged Buyout Industry, 75 AM. Soc. REV. 894 (2010) on the disadvantages faced by women in what the author argues is a culturally male leverage buyout industry.

13. For a cross-national review of the status of women in the world's leading professions, see WOMEN IN THE WORLD'S LEGAL PROFESSIONS (Ulrike Schultz \& Gisela Shaw eds., 2003). For a more recent review of the literature on women in the legal profession, see Fiona M. Kay \& Elizabeth Gorman, Women in the Legal Profession, 4 ANNUAL REV. OF L. \& Soc. SCI. 299 (2008). Specifically, see where Kay and Gorman's review covers strides in legal education, $i d$. at 301, organizational barriers at entry and hiring, id. at 303, perception, $i d$. at 315 , experience once within the firm, $i d$. at 305 , especially surrounding sexual harassment, $i d$. at 307 , family choices, id., and final outcomes like promotions, $i d$. at 309, wage gap, id. at 311-14, and quitting, id. at 316-17. For specific accounts on the legal profession, see Kay and Hagan's work on women's disadvantages in collecting different types of cultural law firm human capital. Fiona M. Kay \& John Hagan, Raising the Bar: The Gender Stratification of Law-Firm Capital, 63 AM. Soc. REV. 728 (1998). See also Jennifer Pierce's work on "mothering" gender-based roles that women fall into while seen within organizational spaces like law firms. Jennifer L. Pierce, Emotional Labor Among Paralegals, 561 AnNALs AM. ACAD. Pol. \& Soc. SCI. 127 (1999). The most seminal work on women within legal organizations and the barriers they face at entry, experience, and success is Cynthia Epstein's early work on the subject that remains deeply relevant while trying to understand gendered trajectories within law firms. See Cynthia Fuchs Epstein, Women In LAW (1993). Specifically, for a review of the barriers to entry and success faced by women in the Indian legal profession, see the recent Rainmaker Report, Sonal Makhija \& Swagata Raha, Challenges Faced By Women in the Legal Profession, RAINMAKeR (2012), http://www.scribd.com/doc/102128508/ChallengesFaced-by-Indian-Women-Legal-Professionals-Full-Report.

14. It was a consistent theme across my interviews with senior women lawyers in law firms $(n=15)$ that gender was not particularly salient in their interactions. Comments like, "Nobody cares if I am a man or a woman ... as long as I get my job done." were common, and yet others suggested that clients sometimes preferred to have women lawyers work on their matters because they actually could be trusted to "get the job done." Author Interview \#2012(k) with Senior Female Associate in a Big Law Firm, in Mumbai (August 21 2012). For interactional effects of gender and status more generally, see infra Section II.B.

15. Ethan Michelson, Women in the Legal Profession, 1970-2010: A Study of the Global Supply of Lawyers, 20 IND. J. GLOBAL LEGAL STUD. 1071, 1075 (2013).

16. Until very recently, there were no entry requirements for entering the legal profession, and graduating from a law university/college with an LL.B degree was enough to enroll with the Bar Council as an advocate. As a result, these numbers might well be 
gender representation that it is salient for India's big law firms to be institutionally capable of fostering gender-neutral advantages for their female associates. My research attempts to preliminarily navigate this new territory of innovation and formal equality within the Indian legal profession. Using in-depth interviews (of at least an hour) with women in senior positions at these global law firms, as well as informant interviews with several other prominent male and female lawyers in the profession more generally, I attempt to ask: (a) How do these women consider the salience of their gender within these big law firms? and (b) If it is indeed the case that these women do not experience the status of gender as we would expect, what factors makes gender relatively nonsalient to these women professionals and the organizations that employ them?

To help unpack these broad questions, in my interviews with these women in high positions within these big law firms, ${ }^{17} \mathrm{I}$ was interested in how gender interacted with their experience at different levels of analysis. First, at the individual level, I was interested in who these women were and the social and cultural factors (e.g. their family background, educational training, etc.) that shaped their potential for success. Second, at the interactional level, I was interested in the networks these women had and/or felt capable of making and the ensuing interactions these offered with clients, peers, superiors, and subordinates. Finally, at the institutional level, the impetus was to hone in on the innovative structural factors that these big law firms were offering that were capable of diverting the persistent effects of a deeply hierarchical gendered profession-what about these new workplaces were allowing for women lawyers to finally come out ahead? What lessons did that have for legal workspace emergence more generally? In this article, I examine these findings and make a preliminary case of their implications for legal workspace emergence in newly global markets.

reporting men and women who are not "active" and practicing lawyers, but merely those who have a legal qualification to practice law. The census data, which Michelson uses, reports practicing lawyers instead of adults with law degrees who are enrolled with a Bar Council. See Michelson, supra note 15.

17. See infra Table 1 (referring to the limited set of large law firms in the Indian context, which are typically between 100 and 500 associates large). See generally MARC Galanter \& Thomas Palay, Tournament of LaWyers: The Transformation of the BIG LAW FIRM (1994) (tracing the rise of one hundred of the United States' top firms in order to diagnose the health of the business of American law). 


\section{A CERTAin Kind Of Woman Does Well: FACtors At The INDiVIDUAL LEVEL}

The partner asked, "How many of you have walked into the room and have people mistake you for a secretary or a paralegal?" To my surprise, everyone had a story of some sort that fed that agenda: about how they were at a constant disadvantage vis-à-vis their male colleagues, not treated as "serious stuff," etc. On the other hand, I had to confess as the only non-white woman from a developing country that I had never felt the same pressures while working in India. If anything, being a woman was an advantage-especially compared to the U.S. ${ }^{18}$

This quote from an early interview for the project set the tone for what would become a repeatedly asked question among these women lawyers. The respondent, who was then a "star" senior associate in one of the big law firms, was recounting an experience from an overseas secondment in a New York law firm. Her relative disorientation with the possibility of gender being a significant variable in legal organizational trajectories ("to my surprise . . . everyone had a story.") sparked a new line of inquiry within this project: Was this a limited example or was there some external validity to the claim that certain female women lawyers in India had never faced professional circumstances where they were regarded differently because of their gender? To get some leverage on these questions, I asked these lawyers about situations where their status as an important corporate lawyer felt threatened, and their response overwhelmingly resonated with the recollection above. ${ }^{19}$ While there were some stories of initial client hesitation of working with a woman lawyer, ${ }^{20}$ there were even more stories about how these women had dedicated repeat clients who not only were ambivalent to their gender, but instead, preferred their

18. Author Interview \#2011(a) with Female Partner in a Big Law Firm, in Mumbai (Aug. 23, 2011).

19. The one exception to this otherwise unanimous response was from a senior lawyer who had started her career doing domestic litigation and property work in what was then a local Bombay law firm. As one of the firms' only female lawyers, she recollects some comments from clients and other lawyers expressing surprise, which she was quick to set aside: "But once they knew what work I was able to handle, then it didn't matter who I was." The respondent is now a senior partner at a Big Law firm. Author Interview \#2012(c) with Female Partner in a Big Law Firm, in Mumbai (June 19, 2012).

20. See Author Interview \#2012(c), supra note 19, about the lawyer who had to face initial wariness from the client, which was, upon continued interaction, remedied. 
services because of how much more they trusted them for their reliability and quality of work. ${ }^{21}$

Similarly, other lawyers commented about how her clients would rather have a woman partner or senior associate on a matter because it "ensured quality." 22 What is more, most women in these law firms reported strong organizational and interactional advantages within the firm, especially in contrast with women in other legal workspaces. For example, women felt like they were much better advantaged in their large law firms when compared to litigation practices, where hierarchical settings were strong. A senior lawyer, when asked about her salience as a woman lawyer, responded:

People don't think of it as an issue-I get the perspective would have been different if I had been a litigating lawyer. For example, when I was interning, my senior was a woman and I know that judges looked at a case differently when a male lawyer was arguing instead of a female lawyer. So if I had been in litigation, it would have been different. But not here, not at all. ${ }^{23}$

This testament to equal treatment in the firm also included more specific remarks about how women fared in relation to their male peers once within the same firm. I have no firm-wide data on any of these firms to test the nature of advancement and success of these women in relation to their male counterparts, but in speaking about their progress and success within the firm, women across firms reported gender as not being a consideration and highlighted how their advancement across the

21. Several lawyers shared a version of this story about how clients preferred having a woman on the case to take care of their matters because women were thought to be more reliable and better overall. For example, one lawyer offered as an extension to the question about whether gender was disadvantageous in interactions with clients for a woman lawyer: “[Yes], Maybe people who are litigating, but the clients we face don't make our gender salient at all. We meet them as a [firm] lawyer. I guess if you were representing a client at a trial court it will be very different. But we never get that from our clients. Within the firm, with our corporate clients, we never feel that way. In fact, a lot of my clients tell me that they prefer a woman because women are a lot more intelligent ... and that they will get the job done . . . and I have heard this from more than a few of my clients." Author Interview \#2012(e) with Female Partner in a Big Law Firm, in Mumbai (Aug. 19, 2012).

22. Recollecting a story about her interactions with clients, this senior associate offered: "I was talking to a client about our team (which has a lot more women than men) and he said 'Oh, it is good you have that composition because I would much rather have a woman partner or senior associate because that ensures quality." Author Interview \#2012(m) with Female Senior Associate in a Big Law Firm, in Mumbai, (Aug. 19, 2012).

23. $I d$. 
tracks within the firm (i.e. across associate and partner levels) was on par with male peers of similar standing. ${ }^{24}$ Of course, there was no particular reason to question the unanimity with which these women reported this lack of gendered framing. ${ }^{25}$ But, given all that we know about women lawyers globally, ${ }^{26}$ and the limited history of women

24. Author Interviews \#2012(a)-(m), (2011-2012). Every response to this question about gender being salient in determining professional rewards was answered with a variation of this quote by a senior law associate: "I don't think so-I have never felt that way. I don't know about other firms, I won't be able to tell you but this firm is very egalitarian. I don't think you are ever looked at differently because you are a woman when it comes to promotions, bonuses, or getting clients. I joined with two other guys at the same time in the same firm and I have never had different opportunities-we were on the same track." Author Interview \#2012(l) with Female Senior Associate in a Big Law Firm, in Mumbai, (Aug. 18, 2012).

25. Having said that, it seems important to include that the possibility of an overreporting bias is not entirely inconceivable. We know from research on minorities that successful candidates are likely to over-report advantages on "making it" within a given organization to avoid being stereotyped with vulnerability and othering. For example, in her work on transgender persons in organizations, Kristen Schilt offers that even though she doubts her respondents were exaggerating their experiences, it was possible that the FTMs in her sample "over-report positive experiences within the workplace to shore up their right to be a man." See Kristen Schilt, Just One of the Guys: How Transmen Make Gender Visible At Work, in SOCIOLOGY OF ORganizATIONS: STRUCTURES AND RELATIONSHIPS (Godwyn et al. eds., 2011).

26. The substantial increase of women in the professional workplace has been an important achievement of the gender movement, but the evidence for this feminization has not been uniformly optimistic. We know that women across the globe have been entering the professions in greater numbers than ever before, but that the pace of advancement is slow and uneven in different countries and cultures. Marilyn J. Davidson \& Ronald J. Burke, Women in Management Worldwide: Progress and Prospects (2011). Research consistently shows that women match or outnumber men in higher education, Myrtle P. Bell, DivERsity IN ORGANIZATIONS (2011), including professional schools, even in countries not known for their gender egalitarianism, Hannah Rosin, THE END OF MEN (2012). At the same time, we know that even if they enter the workplace with similar credentials and expectations, their career paths quickly diverge, ADVANCING Women's Careers: Research AND PRACTICE (Ronald J. Burke \& Debra L. Nelson eds., 2002), leaving women at the unequal end of workplace rewards like promotions, pay, and bonuses. With particular focus on the legal profession, research shows that there are now considerably more women graduating from law schools, Gita Z. Wilder, Law School Debt and Urban Law Schools, 36 Sw. UL REV. 509 (2007), and that this rise in feminization is consistent across nations, Shultz \& Shaw, supra note 13; Michelson, supra note 15 . At the same time, while recent workplace accounts are not as drastic as early workplace accounts riddled with discrimination and ceilings, EPSTEIN, supra note 13, there continues to be evidence of gender-typed biases and treatment within law schools. For example, Robert Granfield offers a portrait of what makes an elite lawyer and how schools can create a stratified environment that leads to the profession, see ROBERT Granfield, Making Elite LaWyers: Visions of LAW AT HaRvard AND BEyond (1992), and legal workspaces, Pierce, supra note 13, alike. 
professionals in India specifically, ${ }^{27}$ it does warrant an introspection of the individual profiles of these women: What about these women prevent their being penalized on the ground of gender?

27. In the Indian context, sociological studies on women and work outside of agriculture remain primarily concerned with the informal sector and low-wage employment (e.g. Swaminathan, 2012; Paul, 2009; Raju \& Bagchi, 1993). With market liberalization, this has expanded to include other type of workforces like outsourcing (Patel, 2010) and export (Jeyaranjan \& Swaminathan, 1999), and the findings of routine, segregated, and task-intensive labor is common (Mukherjee, 2005). But these findings are too limited for our purposes since they do not study women in high status or professional workforces. To the extent that there is research on professional workforces, there is confirmation for an essentialist prejudice to feminization in select family-friendly subfields like OB/GYN for women doctors (Sood \& Chadda, 2010), "customer-relations" friendly human resource positions for women managers (Gupta et al, 1998), or communication-related manager posts for female engineers (Patel \& Parmentier, 2005). In addition, research on women within high prestige professional tracks shows that they are subject to persistent gender role expectations and penalty for deviance. For instance, Patel \& Parmentier (2005) show that female engineers in India from elite engineering schools (IITs) continue to be on the periphery of employing organizations with large socio-economic disparities when compared to their male peers. Work on women in academia and science more generally (Gupta and Sharma: 2003) show that there is a strong partifocal bias to female participation and promotion within elite organizations. Other research on highly-educated women show that while women match and sometimes surpass men at entry levels within prestigious organizations, they advance at rates that are much less significant than their male peers who started with them (Kumar: 2001). Similarly, research on women in the Indian managerial workforce testifies to strong entry constraints (Desai: 1977, Jain: 1975), fewer opportunities for within-organization training and education (Buddhapriya, 1999), a resistance to women in positions of power (Naqvi, 2011), and an overall male bias (Gulhati, 1990), even among managers who think of their organizations as meritocratic (Gupta et al: 1998). Thus, in the Indian case more generally, workforce feminization has followed this expected trend of being either essentialism-driven or low prestige. And in the few cases where highly-educated women have managed to break entry barriers into prestigious workforces, their advancement and value has varied significantly from their male peers. See SANGHAMITRA BUDDHAPRIYA, Women In MANAGEMent (1999); NeERA DESAI, WoMen IN MOdeRn INDIA (1977); J. Jeyaranjan \& Padmini Swaminathan, Resilience of Gender Inequities: Women and Employment in Chennai, 34 ECON. \& POL. WKLY. 16 (1999); Kaval Gulhati, Attitudes Toward Women Managers: Comparison of Attitudes of Male and Female Managers in India, 25 ECON. \& POL. WKLY. M41 (1990); Ashok Gupta et al., Women Managers in India: Challenges and opportunities, 17 EQUAL OPPORTUNITIES INT'L 4 (1998); Namrata Gupta \& Arun K. Sharma, Patrifocal Concerns in the Lives of Women in Academic Science: Continuity of Tradition and Emerging Challenges, 10 INDIAN J. GEND. STUD. 279 (2003); Neelam Kumar, Gender and Stratification in Science An Empirical Study in the Indian Setting, 8 Indian J. GEnd. STUd. 51 (2001); Mukul Mukherjee, Women and Work in the Shadow of Globalization, 11 InDIAN J. GEND. STUD. 275 (2004); Farah Naqvi, Perspectives of Indian Women Managers in the Public Sector, 18 Indan J. GEND. STUD. 279 (2011); Reena Patel, Working the Night Shift: Women in India's Call Center Industry (2010); Reena Patel \& Mary Jane C. Parmentier, The Persistence of Traditional Gender Roles in the Information Technology Sector: A Study of Female Engineers in India, 2 INFo. TeCh. \& InT'L Dev. 29 (2005); Tinku Paul, Women EMpowerment Through Work 


\section{A. "Me? A Secretary?": The Interactions of Gender and Class}

While on the subject of whether she was ever mistaken to be a secretary in her career, a senior lawyer interjected my question midway with the following quote: "OH MY GOD. That would never happen. My clients would never think I was not a lawyer." 28 This disassociation with the possibility of being seen as a secretary could mean that women lawyers in positions of power were not curtailed by the same limitations of their counterparts in other countries, but it also speaks in some sense to the possible class extensions that might be critical in understanding the position of these successful women. Critical stratification scholars have long credited the unique power of intersectionality (i.e. the need to include and contrast all dimensions and minority identities) in understanding disadvantage and discrimination. ${ }^{29} \mathrm{~A}$ similar extension of this framework is useful in understanding the success of these big law firm women lawyers. Put simply, the question would be: Do all women have the same advantages within large law firms? Or is the advantage limited to certain kinds of women?

For instance, it would be futile to argue that the seemingly gender-blind experiences of these women lawyers were somehow independent of the class-based privileges that they enjoyed. Although it is impossible to generalize the workings of class in a heterogeneous

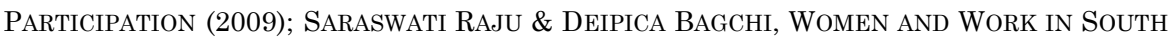
Asia: Regional Patterns and Perspectives (1993); Mamta Sood \& R. K. Chadda, Women in Medicine A Perspective, 17 Indian J. GEND. STUD. 277 (2010); Women AND WoRK (Padmini Swaminathan ed. 2012).

28. Author Interview \#2012 (b) with Female Partner in a Big Law Firm, in Mumbai (June 19, 2012).

29. Critical feminist scholars have long resisted the pigeonholing of the effects of gender without taking into account the additional intersectional effects of factors like race and class. For example, in her seminal book UNEQUAL CHILDHOODS, which studied intersectional inequality among children and child-rearing practices, sociologist Annette Lareau offered that parenting explanations traditionally attributed to race were often mediated by class. In other words, middle-class parents-holding race constant-were more likely to raise their children similarly than parents of the same race who were differentiated by class. See AnNette Lareau, Unequal Childhoods: Class, Race, and FAMILY LIFE (2003) (analyzing how social class shapes parenting in unexpected fashion in white and African-American families). For a review of the empirical studies that trace the effects of race and gender intersectionality in U.S. labor markets on wage inequality, stereotype threat, and domestic labor, see Irene Browne \& Joya Misra, The Intersection of Gender and Race in the Labor Market, 29 ANNUAL REV. Soc. 487 (2003). Still other authors focus on institutional factors. For example, European scholarship on gender and class has explored the effects of structural and political inequalities while trying to understand the intersectionalities between race, class, gender, and sexuality. See Mieke Verloo, Multiple Inequalities, Intersectionality and the European Union, 13 EUR. J. WOMEN's STUD. 211 (2006). 
country like India, especially without demographic data across sites on these lawyers, I would argue that it is not too much of an extension to assume that at least some part of this advantage is negotiated by the social and cultural standing of the women in question. Thus, while less optimistic, it is possible-and certainly more likely-that these particular women were spared from misrecognition as secretaries and paralegals not because all Indian women in the workplace had suddenly achieved a new social standing, but instead, because something about these particular lawyers signaled a class effect that mediated their gender. ${ }^{30} \mathrm{~A}$ typical big law lawyer, as Table 2 below indicates, is not just successful; she is also the inheritor of certain types of social and cultural capital. She usually goes to a certain kind of English-speaking high school, graduates from a National Law School, and comes from a highly educated and/or professionally well-connected family. No doubt, it is no longer the case that the only acquirers of prestigious legal positions are sons of well-connected lawyers, judges, or political figures. Yet, at the same time, inheritors of these coveted positions within large law firms are part of an intellectual and cultural elite too, in their own way.

\section{B. Partner by Thirty: The Advantage of the Five-Year Program}

There are other factors that seal homogeneity among this cohort of successful professionals, key among which is their age. As law graduates from these new five-year undergraduate law programs, these women are not only rigorously trained, they are also in a position to leverage their career prospects in a manner amenable to their life course timeline. Compared to their North American peers, who are likely to finish their first degrees by twenty-one and-assuming, optimistically, that they go straight through to law school-graduate and start their grueling law tenure tracks in their mid-twenties, the trajectory of a potential Indian big law firm lawyer is certainly privileged. Having graduated at twenty-two, these women are well poised-and certainly as capable as their male peers-to work the regular twelve to fifteen hour work shifts, pull all-nighters for transaction deadlines, and make allied sacrifices traditionally expected from early associates in time to be on partnership track by the time they are in their late twenties.

30. See generally Angela L. Melville \& Frank H. Stephen, The More Things Change, the More They Stay the Same: Explaining Stratification Within the Faculty of Advocates, Scotland, 18 INT'L J. LEGAL PROF. 211 (2011) (making a similar argument about how class mediates gender in the Scottish legal profession where, in spite of an increasing number of women entering the profession, there remains discrimination and stratification that is deeply undercutting working-class aspirants). 
At the same time, these sacrifices are not necessarily made at the risk of having a stable relationship or a family. Many of the women I interviewed were in committed relationships or marriages, although very few of them had children. And while it was somewhat unorthodox for Indian women to be planning families in their thirties, it was not unheard of, and it certainly did not place them in a situation where they were necessarily making strict family versus job choices. In fact, in one of the firms where I was interviewing lawyers, three senior partners (all in their thirties) were expecting their first children in the summer of 2012 , as much of this research was underway. For senior associates who were not personally thinking of these choices in the immediate or short terms, there seemed to be recognition that these family choices in the future could differentiate their career prospects from their male peers at that stage. This, however, is not to say that marriage and children are not real and persistent barriers to entry and success within these professions. A recent report, which addresses the challenges faced by women in the Indian legal profession more broadly, ${ }^{31}$ revealed that most women did find decisions about marriage and family to be barriers at work. ${ }^{32}$ Yet, at the same time, given their advancement thus far, they felt better suited to negotiate these decisions than they might have been in traditional law firms or earlier in their careers. Take, for example, a senior associate in a big law firm in Mumbai who was recruited at the end of her last year in law school:

In our interviews, they never ask questions about children or families. . . They ask question(s) that might get at ambition, I guess, but I don't think the questions they asked me would have allowed them to judge whether I wanted a child or family. At least the way

31. See Makhija \& Raha, supra note 13. While firms were sampled in the report (29.2\%), they were predominantly Delhi-based firms (only $10 \%$ of the total sample was from the Mumbai Big Law firm population). This further suggests that there might be something about the culture of these Mumbai firms that further advantages these women. For a fuller research methodology, see $i d$. at 4-5. For information on demographics, including sectors and cities in the sample, age profile, experience, qualifications, income, and family structures, see $i d$. at 6-13.

32. In the survey conducted by the study above, respondents admitted to being questioned about marital status (50\%) and children (62\%) in their job interviews, and a majority $(68 \%)$ considered these factors to be barriers to their entry and success in the profession. $I d$. at $41,43,48$, respectively. 
they interviewed me, I don't think it was something they could gauge. ${ }^{33}$

This interaction with a similarly-positioned associate about the relative distance these women can afford to have about parenthood choices makes the advantage of age a little clearer:

We [referring to her peer group of senior lawyers] are at a stage where there are many women but most of us don't have children and aren't immediately planning on having children. There is no immediate sense of this parenthood culture [she says this with emphasis, using air quotes]. If you look at the women in senior positions, they are either not married or are married and don't have children yet . . . But three partners right now are pregnant, and it is the first time this is happening. ${ }^{34}$

\section{Why This Case Is Unique: Even If Only for a Certain Kind of Woman Lawyer}

While being mindful of the class and gender intersectionalities in the current case, it would be a simplistic explanation to assume that the trajectory of success for these well-educated women from professional-parent families is attributable merely to class. Although these women no doubt have the advantage of familial and communal structures, there are other women with similar advantages who are not in a position to unpack these advantages. ${ }^{35}$ Thus, while this kind of high

33. Author Interview \#2012 (i) with Female Senior Associate in a Big Law Firm, in Mumbai (Aug. 23, 2012) (emphasis applied, "our" referring to a big law firm).

34. Author Interview \#2012 (l) with Female Senior Associate in a Big Law Firm, in Mumbai (Aug. 19, 2012).

35. An analysis of women in different organizations within the Indian legal profession is outside the scope of this paper, although I do deal with it in my larger project on women lawyers across comparable organizations. Preliminary findings from these comparative data are available with the Harvard GLEE Project. However, Michelson's recent work on the demography of feminization is striking evidence of the fact that women are not only flailing in the broader professional spaces. See Michelson, supra note 15. Even so, there are other broad, demographic figures that offer some direction to the state of women in the larger profession: women are, as traditional accounts of the professions would suggest, even more sparsely distributed in positions of power than in the profession overall. For instance, as of 2012, of the 294 lawyers who have been promoted to the position of Senior Advocate in the Supreme Court, only five (or about 2\%) have been women (SCI Official Statistics, 2012). If we were to take into account the demographic history of judges in the Indian Supreme Court, the story remains depressing as far as female representation is concerned: for among the 204 judges in the sixty-three year-old history of India's Supreme 
socio-economic status, educated, and sophisticated woman preceded the onslaught of these new organizations (i.e. large law firms), ${ }^{36}$ it is not until recently that these concentrated reports of organizational success stories have come to pass. And not only is this disparity a thing of the past: similarly-placed women in other kinds of legal practice in India-especially women in traditional, male-hierarchical work structures like litigation-continue to face strong barriers to entry and success notwithstanding their credential, social upbringing, and class. ${ }^{37}$ Thus, while these big law firms might certainly favor and champion a certain kind of successful woman lawyer, it remains of note that even this sort of lawyer has only certain avenues for receiving these accolades within the steeply stratified professions. As one lawyer suggests:

I think we are probably-most of the people who come here would never be mistaken for anything but a lawyer because we come from a certain strata of society. But I don't know about other professions-my brother is a doctor with the armed forces and there you can see the distinction between the ranks-and that is something he has told me about. Women, for example, don't get promotions and if you have kids, then the penalty is obvious. (It is a ) very hierarchical organization and my sister in law-who is also a doctor-tells me stories

Court, only five (or less than 2.5\%) have been women (SCI Official Statistics, 2013). To take a more generous account of "seniority" and "success" within the profession, one could consider the other elevation to status within litigation practice in the Supreme Court: the promotion to the position of an Advocate-on-Record by the Court. As the only lawyers with the right to file pleadings before the Supreme Court, Advocates-on-Record hold a certain elevated status in contrast to the rest of the Bar, although nowhere as high as that held by senior advocates, grand advocates, or judges. Even in this intermediate level of prestige, women are only marginally better represented. Of the 1744 Advocates-on-Record in the Supreme Court as of 2012, 230 (or 13\%) were women (SCI Official Statistics, 2012). See Supreme Court Advocate on Record List as on 22.05.2012, SUPREME COURT OF INDIA GOVERNMENT WEBSITE, http://supremecourtofindia.nic.in/circular/advocateonrecord.pdf (last visited Feb. 11, 2013); Supreme Court List of Senior Advocates Designated by the Supreme Court as on 17.12.2012, SUPREME COURT OF INDIA GOVERNMENT WeBSITE, http://supremecourtof india.nic.in/outtoday/sradv17122012.pdf (last visited Feb. 11, 2013).

36. See Krishnan, supra note 1, at 3 (use of the RSG report to explain the newness of these firms).

37. For a review of the barriers to entry and success faced by women in the Indian legal profession, see Makhija \& Raha, supra note 13. 
about how she is not at all taken seriously ... and this is different from anything I have experienced. ${ }^{38}$

\section{The BoArdroom Behaves Better When There Are Women: INTERACTIONAL EFFECTS}

While factors at the individual level are no doubt important for the success of these women within these firms, the power and agency leveraged by them in interactions with superiors, peers, clients, and the organization generally are equally pertinent to the construction of their experience. Here, I focus on three emergent themes in these interactional accounts from the data: (a) the power of close ties with superiors in negotiating personal career trajectories, (b) the positive salience of gender in client expectations and interactions, and (c) the overall value of deference as a valuable characteristic in these interactions.

\section{A. Power of Close Ties}

Much as we would expect, successful women lawyers in these large firms have close ties with the teams they work with, cordial relationships with their superiors, and particularly deep ties with their clients. Not only were these ties important, they were deeply negotiated at the personal level-there were numerous examples of how being "close to [the boss/partner]" or "having an equation" where [the reporting partner] "gets that I will work as hard as anyone else and understands that I am not flaking [rolls eyes, exaggeratedly] if I have to leave early sometimes" made work lives deeply rewarding and uncompromised for these successful women. ${ }^{39}$ As one partner remarked:

I still manage on most days to [get to] sleep at $10 \mathrm{pm}$, get up at 6 am, play squash every day, have my breakfast and read my paper with my morning tea. I

38. Author Interview \#2012 (m) with Female Senior Associate in a Big Law Firm, in Mumbai (Aug. 19, 2012).

39. This sense of agency that these women feel with their time was not uncommon. Another senior partner who took her personal time seriously commented on how she worked around the long hours in the firm by waking up early and making the mornings her personal time. "No one gets here (to the firm) till about 10:30-11:00," she says, "and I am an early riser-so I just make the mornings mine: I play golf, I catch up with my friends, I get some nariyal pani (tender coconut water) —and then I am ready to start the day and put in all the long hours." Author Interview \#2012(c) with Female Partner in a Big Law Firm, in Mumbai (June 19, 2012). 
work solid hours, yes-but I have not had to compromise on anything. ${ }^{40}$

It is not surprising that in the early emergence of these firms, there is still leeway to negotiate work culture and hierarchy in new ways, but the problem with this personal negotiation is that it is personal-leaving women incapable of leveraging these networks at a disadvantage. For instance, between two women of equal age that had children of the same age, one was able to have a more flexible workload while still holding a prominent place in the firm while she felt like her colleague's trajectory was more volatile. The difference (according to the woman who had managed to successfully leverage an advantage with her balance of work and family) was that she was able to sit down and tell the managing partner that her son needed her in the house at certain specific times, but that she would still do her work once she had put him down to bed. Her recollection of the situation was an extension of the ease with which she was able to negotiate this compromise between work and family. ${ }^{41}$ But one cannot help but notice that this cordial, peaceful negotiation might have also been made especially possible because of a "personal connection" this lawyer had with her reporting partners. ${ }^{42}$ In her words: "It all comes down to what your relationship with them is, yaar." 43 These interpersonal relationships that determine special advantages might be empowering for women capable of making them, but they leave many others incapable of harnessing this interactional capital in the lurch.

40. Author Interview \#2011(a) with Female Partner in a Big Law Firm, in Mumbai (Aug. 23 2011).

41. In her relaying of the recollection of the negotiation to me, her tone remained positive. The reporting partners in question had been supporting, giving her the signal to do whatever was necessary to make the balance workable for her. She says, "They (the management) are really accommodating - but you have to ask them." Author Interview \#2012(g) with Female Senior Associate in a Big Law Firm, in Mumbai (June 20, 2012).

42. This particular senior associate was not related or personally connected with the management or any of the partners. But she did feel like she had a connection with them because she was capable of making one. It might have helped, she agreed as I prodded, that her family was from the same regional area as the managing partners, and she too was an old Mumbai resident: "but that isn't why I have the connection," she said. Author Interview \#2012(g) with Female Senior Associate in a Big Law Firm, in Mumbai (June 20, 2012).

43. Author Interview \#2012(g) with Female Senior Associate in a Big Law Firm, in Mumbai (June 20, 2012). 


\section{B. Clients Want Us: The Positive Salience of Gender in Client Interactions}

When asked whether gender was salient in interactions with clients, a common response was either "clients don't care" or "clients want women lawyers." 44 The seemingly gender-neutral work atmosphere these women enjoyed seemed not just egalitarian as per these accounts, but in some sense, even favorable. Take, for example, one senior associate's recollection about her client's (a large corporation that was staffed by a predominantly male transactional team) choice for senior female lawyer representing them in a transaction:

Attorney: I was talking to a client about our team (which she explained as having a lot more women than men) and he said "Oh, it is good you have that composition because I would much rather have a woman partner or senior associate because that ensures quality.”

Author: What do you think they mean by "quality"?

Attorney: Clients that tell me that they want women lawyers also tell us that women work better in negotiations ... (they are) not taken aback by the antics of the male lawyer.

Author: What kind of "antics"?

Attorney: Compare two situations: a man and a woman in a boardroom works better than two men or two women on opposing sides . . . because, then, the ego crops up and everyone is immediately on edge-everyone wants to show who is boss. But when there is a man and a woman, everyone is more polite. Substantively, what you are saying doesn't change but the politeness helps the transaction. ${ }^{45}$

Similarly, another partner recalled how a lot of her clients preferred her because they knew that with her team, "the job would get done." Another partner agreed that while sometimes it was a bit of a hurdle to

44. Emphasis added.

45. Author Interview \#2012(m) with Female Senior Associate in a Big Law Firm, in Mumbai (Aug. 19, 2012). 
handle traditional male clients who had never worked on a transaction with a woman lawyer, it all changed once they began working together; "Sometimes the most traditional clients-they wait till they are sure-but once you have them, they won't leave you."

Yet, this was not self-reporting alone. Senior male partners who worked alongside these women lawyers often referred to them as "hard working," "careful," and "dedicated." And although this representation was not always in the rhetoric of preference in reference to men, there was certainly an agreement on the suitability of these traits for staffing a given transaction. In general, this characterization of these well-positioned women as careful, dedicated, and most capable of getting the job done is not uncommon, ${ }^{46}$ and it is certainly the case that it is making gender positively salient in these successful careers. But, in the long run, it could be problematic because it reinforces certain assumed stereotypes about gender roles and gives them precedence over actual professional roles that these women employ. 47

46. See supra note 21, about clients preferring women because they were more likely to deliver reliable, quality work. See also Author Interview \#2012(j) with Female Senior Associate in a Big Law Firm, in Mumbai (Aug. 19, 2012) (where the partner in question described her clients' perception of her (and her peers') work as disciplined and dedicated). Similarly, in the broader literature on women within high status professional organizational spaces, we know that scholars have theorized using empirical data that women and men have certain expected roles within organizations. See RosabeTH Moss KANTER, MEN AND WOMEN OF THE CORPORATION (1977). We know that these assumed roles stick: for example, Cecilia Ridgeway argues that gender frames are used to locate and judge women to their detriment. "The enactment of inequality, however, is accomplished through the enactment of gender difference . . . that implies and creates the inequality." See Cecilia L. Ridgeway, Framed Before We Know It: How Gender Shapes Social Relations, 23 GEND. \& SOC'Y 145, 151 (2009). We also know that the backlash for women who move away from these roles is more harsh than for men who move away from these roles. See Laurie A. Rudman \& Peter Glick, Prescriptive Gender Stereotypes and Backlash Toward Agentic Women, 57 J. Soc. Issues 743, 758-59 (2001).

47. For instance, Pierce's ethnographic study of a large law firm in San Francisco, reports that women litigators, even if aggressive in the courtroom-persona, are required to adhere to a nurturing, emotional standard within the law firm in order to be able to win appreciation from their peers and subordinates. "Unlike male attorneys, women encounter a double bind in the aggressive component of emotional labor . . women were criticized for being 'too nice to the witnesses' or 'not forceful enough,' 'too bashful,' and 'unaggressive." See JenNifer PIERCE, GENDER TRIALs: EMOtional Lives IN CONTEMPORARY LAW FIRMS 114 (1996). 


\section{Advantaged Gender Roles and the Value of Deference}

One of the extensions of women professionals being typecast by set gender roles like "careful," "dedicated," "polite," or "emotional" is that it sets their identity as a woman more predominantly than their identity as a professional. Transgressions from these roles are penalized, but at the same time, the roles themselves are professionally incongruous with rewards. The most common example of this is the expected quality of deference from women professionals that research has shown, at least in Western workspaces, to be detrimental to their career rewards. ${ }^{48}$ Women are expected, based on gendered expectations, to be deferent, cordial, and not demanding. At the same time, a common refrain for why women do not do well is because, put simply, "they don't ask." 49 Women are seen as not forthcoming enough to negotiate for themselves, to ask for rewards, or to demand promotions. As a result, because they "ask" for less, they "get" less.

However, it could be argued that this framework penalizing deference operates under the assumption of a system where aggressive negotiation and agency in the workplace are consistently valued. In the Indian example, the reaction to deference was somewhat different. As expected, most women lawyers admitted to being less aggressive than their male peers, attributing it often to their socialization. (For example, "I don't think 'oh, I am a woman, I should talk like this' but it is just natural to me-all our lives we have spoken and behaved a particular way. I am not going to change now." ${ }^{50}$ ) At the same time, they thought this lack of aggression could be useful, especially while negotiating raises and demanding caseloads. For instance, a partner, who insisted

48. For example, while talking about emotional labor more generally in the legal workplace, Pierce suggests that deference is the first component of the paralegal behavior expected of paralegals, $i d$. at $89,96,98$, since good paralegals, "like good wives, must be uncritical," id. at 95. At the same time, paralegals are also not seen as being in-line for promotion within the firm. Id. at 41. More broadly, Linda Babcock and Sara Laschever's book on women's deference and resultant professional stagnation is relevant. See Linda Babcock et al., Nice Girls Don't Ask, 81 HARV. Bus. Rev. 14 (2003).

49. Babcock and Laschever, in their research on the gender divide across different settings, argue that one of the reasons women do not get ahead at the same rate as men is because they are not as vocal or assertive about what they could potentially deserve. In addition to various institutional and interactional factors that they borrow from the broad literature on women in the workplace, they suggest that equally key is women holding themselves back. "[S]o, if you don't speak up, you only have yourself to blame if something goes wrong." LINDA BABCOCK \& SARA LASCHEVER, WOMEN DON’T ASK: NEGOTIATION AND THE GENDER DIVIDE 38 (2008).

50. Author Interview \#2012(l) with Female Senior Associate in a Big Law Firm, in Mumbai (Aug. 18, 2012). 
that she did not "need to be aggressive" to match her male peers, offered an explanation:

I would never kick up a fuss about a raise or demand to be put on a certain matter. And because I am not pushy like that, it is more likely to be given to me, the [managing partner] is more likely to work with me, more likely to give me the matter, than he is with $\mathrm{X}$ [the male partner peer], who is "being an ass" by asking for these things. ${ }^{51}$

This limited data suggests that the idea and valorization of deference in the Indian context-at least in these lawyers' minds-is certainly peculiar. It could be that in the Indian context, agentic professionals-men and women-have a backlash because no aggression is rewarded within these workspaces, and women, who are more likely to be socialized in manners that exhibit this deference, are rewarded doubly. While this is certainly one possibility, my current data is incapable of speaking to this theory because it does not investigate this issue with variation from a counter-namely male-standpoint. How do senior male lawyer interactions correspond and compare with these successful women attorneys? Do they think their interactions are valued differently? What does this difference tell us about the valuation of aggression and deference? This data suggests that these questions are important to ask in future research, but it does not itself provide answers.

\section{NeW WoRK, NeW Frames: Institutional AdVANTAGES of Big LaW WORK}

While individual characteristics and interactional dynamics are central to understanding these women in senior positions within large Indian law firms, their context fades without triangulation with institutional factors. In particular, two broad institutional factors might push these women into these firms and support them once they enter: ${ }^{52}$

51. Author Interview \#2011(a) with Female Partner in a Big Law Firm, in Mumbai (Aug. 23 2011).

52. This institutional comparison is part of the larger project on Globalization of Lawyers in Emerging Economies where I compare and contrast the experience of women lawyers in different organizational forms. For a detailed report on this, see Globalization, Lawyers, and Emerging Economies, HARV. L. SCH., http://www.law.harvard.edu/programs /plp/pages/glee.php (last visited March 7, 2013). The research questions I pursue in this 
(a) the gender-hostile remainder of the legal profession more generally, and (b) the peculiar structural qualities of these specific firms.

\section{A. Gender Hostility in the Greater Legal Profession}

The gender-hostile environment of the Indian legal profession more generally is crucial in trying to understand the successes of women in these emerging, new organizations. In other words, gender would have been particularly salient in traditional choices of legal practice that these women could have made-be it as a junior to a practicing lawyer, joining a small litigation practice, or starting one's own legal practice in a local or national court. And this advantage of being in a firm instead is not lost on them. A common theme in these interviews was the distance these women felt from the experience they might have had outside the firm. For instance, in response to a question about whether she felt like a minority in the profession, this recent partner remarked:

(asking herself the parts of the question I had just asked her in a low voice) H'm . . . is gender salient? . . . Do you think of yourself as a minority?

(then, to me) Within the firm? Of course not ... Within the profession? (pause) I don't think anymore. Maybe in litigation-but not in these type of (referring to the large firm she worked for) corporate law firms. ${ }^{53}$

And it was not only women partners who felt this way. When I asked the (male) managing partner of the firm about diversity, he was quick to offer details about the rich regional, language, and ethnic variation of his workforce. When I primed him further for women and diversity, his answer was quick: "How are women [emphasis added to denote his shocked tone] diverse?"54

This blanket dissonance from the reality of low feminization within the vast remainder of the profession is interesting theoretically because it reveals the power new organizations (these large law firms) have to set prevailing norms and assumptions (gender egalitarian professional spaces). It is important, however, because it suggests one reason for why

paper are limited by my interest in giving the large law firm context descriptive depth to the extent possible with these data.

53. Author Interview \#2012(d) with Female Partner in a Big Law Firm, in Mumbai (June 19, 2012).

54. Author Reference Interview \#2 with Male Senior Equity Partner, in Mumbai (June 2012). 
these women might be committed to doing well within these firms: there are not many other places where their commitment is likely to pay off as well. These firms offer a welcome and unique organizational deviation for the highly-educated woman lawyer who wants to pursue a domestic legal career in a gender-egalitarian environment, and in the gender hostile remainder of the profession, that is a luxury.

\section{B. Structural Advantages: What Makes This Innovative Work Culture Possible?}

In any organizational emergence story, building truly innovative workspaces is difficult because old frameworks of operation and management always attach themselves to new forms. In this case, conventional logic would assume that any new firm would have typically followed in adopting the same hierarchies that reflect the rest of the environment it is embedded in-in other words, these new law firms should have been as steeply gendered as the professional framework they sprouted from. So the question arises: How have these law firms managed to differentiate themselves from the larger gender-bound profession? One explanation is that a number of structural qualities of these firms are particularly conducive to the construction of new gendered hierarchies. First, these firms do mainly international transactional work, which is a new type of legal work that is very recent in the history of the Indian profession. ${ }^{55}$ Second, they do this work for global clients. Thus, even if there was a slight threat that this transactional work might have been seen as nonprestigious, the fact that it is done for large, important, and world-renowned corporate clients instantly makes it newly prestigious in addition to being different. ${ }^{56}$ Third, these firms themselves are organizationally structured unlike any of their predecessors: they are not small-scale family run practices, they do not rely on close kin and ties to recruit, and their processes and standards are increasingly global. In turn, these

55. For a review of the impact of globalization in reorganizing markets and the profession, see David B. Wilkins \& Mihaela Papa, Globalization, Lawyers and India: Towards a Theoretical Synthesis of Globalization Studies and the Sociology of the Legal Profession, INT'L J. LEGAL PROF. 1, 3 (2012).

56. Prestige as a function of client-type and monetary professional rewards is part of an established literature on professional stratification. For a review of the literature and a comparison of competing hypothesis, see Rebecca L Sandefur, Work And Honor In The Law: Prestige And The Division Of Lawyers' Labor, 66 AM. Soc. REv. 382 (2001). For a review of professional prestige and its changing impact on the Indian legal profession given globalization and outsourcing, see Swethaa Ballakrishnen, "I Love My American Job": Professional Prestige in the Indian Outsourcing Industry and Global Consequences of an Expanding Legal Profession, 19 INT'L J. LEGAL PROF. 379 (2012). 
new structures, together with the recent nature of their work, allow them to be truly unlike any other preceding organization: these firms did not just sprout from the existing professional framework-they emerged as a response to the external stimuli of globalization. And perhaps for this reason, negotiation of hierarchies within them is less set as compared to other sites of Indian legal practice.

\section{Maybe Gender Is SAlient: Limitations of the Data AND CONCLUSIONS}

This data suggesting the ability to negotiate gender hierarchies within these firms is no doubt promising for women and emerging organizations alike, but the findings are certainly limited by important caveats. First, there is no direct comparative case here, 57 either at the individual level (i.e. male lawyers) or the organizational level (i.e. women in litigation or in companies), because these in-depth interviews were only with women in law firms. While this is certainly an important perspective to record and understand, we lose in comparison what we gain in insight and depth. Second, these firms are mostly in Mumbai-India's financial capital and a city whose big firm culture is more distinctly malleable by globalization than, say, Delhi, where large law firms could be differently institutionalized. ${ }^{58}$ Again, the current data does not extend itself to make this comparison well, but other reports on women in the profession that have predominantly focused on the profession in other cities have very distinct findings.

Third, the limitation of observations with people in these firms is that it leaves an important section of the population from its purview: women who leave these firms. I could not get systematic data access to women who left these firms and the reasons for their attrition. And to truly understand the experience of these organizational forms and the barriers that impede success within them, understanding why women leave these firms is as crucial as understanding how they succeed within them. Fourth, the entire advantage crafted by these experiences might be a function of age. And the reasons I suggest as advantages-the

57. For a comparative case at the organizational level, see Globalization, Lawyers, and Emerging Economies, supra note 52, where I contrast these women in law firms with women in litigation and in other legal organizations. Although the current data has some perspective from male lawyers from informant interviews, I am currently in the process of collecting main interview data for these lawyers.

58. Women I spoke with in Mumbai would often reference how "this would have been different in Delhi" while explaining their particular advantage in their large law firm or mentioning "friends from law school" who, in their words "had it very different" in a similarly placed law firm in another city. 
institutional novelty of these firms and the ability of these women to balance their work-might be short-lived advantages. It is no doubt true that these women flourish because the challenges of motherhood and young children-traditional laxatives of attrition-are not yet fully matured in their individual cases. But, as these firms grow in size and respond to larger market requirements, more women in later stages of their lives and careers will have to make choices that balance work and family. At this stage in the project, it seems possible to be optimistic that gender will not be salient, but contrasting it with other evidence from the field leaves at least some room for doubt. For instance, the Rainmaker report, which focused on a slightly more senior demographic of women (the average age was thirty-four years with more than a third of the population having over ten years of practice) seemed to give the impression that most women lawyers did think that motherhood was a strong barrier to career rewards. ${ }^{59}$ Finally, it could be that, given how few advantages there are for advancement within the profession, women who do succeed tend to self-report even greater advantages than they are receiving. While there is no reason to believe that these women who claim to play squash and not compromise are misstating their experience, it is possible that they have some dissonance between that experience and the exact career advantage it renders them. Of course, without systematic data on their promotion and rewards, making absolute comparisons is difficult. But other reports from the field seem to suggest a similar dissonance: the Rainmaker Study, for example, suggests that most women feel like they had an equal-or at least some-balance between work and life, 60 and yet, at the same time, almost 90 percent of the sample reported home-work related factors as some of the strongest barriers at work. ${ }^{61}$ Thus, women were quick to confirm advantage in general but had to be pushed to tease out specific barriers they had to overcome to access these advantages.

The laying out of these limitations does not take away from the fact that this is an important time in the history of the Indian legal profession. These women who are unlocking unprecedented success

59. For instance, $75 \%$ of women in law firms who took the survey agreed that the maternity break did have an adverse impact on their career (as compared to $52 \%$ women in litigation and $43 \%$ of the women who worked in companies). See Makhija \& Raha, supra note 13 , at 70 .

60. See Makhija \& Raha, supra note 13. Over half the sample $(n=150)$ of women lawyers in the Rainmaker Survey released in 2012 reported having an equal work-life balance, $i d$. at 36 , while another $42 \%$ felt that, while they spent more time at work, they had some balance between work and life.

61. $90 \%$ of the sample thought the lack of flexible hours and home-related barriers like pressures to start a family $(77 \%)$ and the lack of day care $(85 \%)$ were the strongest barriers at work. See Makhija \& Raha, supra note 13, at 48. 
within environments that do not prime their gender are a unique case not just in the context of the specific gender-hostile Indian legal environment, but in the history of the legal profession more globally. But now that some sources of these advantages have been located, more research is required to make the comparisons set up above to truly unpack the mechanisms that can explain these optimistic aberrations. It is only then that we can begin to make meaningful inquiry into the emergence and sustainability of the nongender-salient professional workplaces. 
ANNEX A: TABLES $1 \& 2$

Table 1. List of All Interviews $(N=24)$

\begin{tabular}{|c|c|c|}
\hline & Women & Men \\
\hline \multicolumn{3}{|l|}{ Main Interviews } \\
\hline Total Number & 15 & -- \\
\hline \multicolumn{3}{|l|}{ Law Firm Size } \\
\hline$>500$ lawyers & 8 & -- \\
\hline$>300$ lawyers & 5 & -- \\
\hline$>100$ lawyers & 2 & -. \\
\hline \multicolumn{3}{|l|}{ Position of Lawyers } \\
\hline Partners & 8 & -- \\
\hline Senior Associates & 7 & -- \\
\hline \multicolumn{3}{|l|}{ Cities } \\
\hline Mumbai & 11 & \\
\hline Bangalore & 4 & \\
\hline \multicolumn{3}{|l|}{ Informant Interviews } \\
\hline Total Number & 2 & 7 \\
\hline Partners in Law Firms & & 4 \\
\hline $\begin{array}{ccc}\begin{array}{l}\text { Senior } \\
\text { Lawyers }\end{array} & \text { Law } & \text { Firm } \\
& & \\
& \end{array}$ & & 1 \\
\hline $\begin{array}{ll}\begin{array}{l}\text { Senior } \\
\text { (Nonfirm) }\end{array} & \text { Lawyers } \\
\end{array}$ & 2 & 1 \\
\hline TOTAL INTERVIEWS & 17 & 7 \\
\hline
\end{tabular}

Notes: (a) Main Interviews were full-length, hour-long interviews, where respondents were questioned about their (i) family and educational background, (ii) work history and experience, and (iii) interactions with superiors, clients, and peers/colleagues. It is the findings from these interviews that form the framework of this paper. (b) Informant Interviews were semi-structured interviews with senior lawyers, both men and women, to help place the Main Interviews in context. While these interviews are not included in the general observations and analysis, they are nonetheless important to position the import of the Main Interview findings. (c) Law Firm Size might seem smaller than big law firms internationally, but see note 11, supra, for an explanation. 
Table 2. Selective Descriptive Characteristics of Main Interview Data $(N=15)$

\begin{tabular}{|c|c|c|}
\hline $\begin{array}{l}S . \\
\text { No. }\end{array}$ & Individual Level Factors & $\%$ Of $N$ \\
\hline 1. & Age & \\
\hline a. & $28-30$ & 0.33 \\
\hline $\mathrm{b}$. & $30-35$ & 0.33 \\
\hline c. & $35-40$ & 0.20 \\
\hline d. & $>40$ & 0.14 \\
\hline 2. & Marital Status & \\
\hline a. & Single & 0.33 \\
\hline b. & Married / Partnered & 0.54 \\
\hline c. & Married / Partnered + Children & 0.13 \\
\hline 3. & Education & \\
\hline a. & National Law School & 0.67 \\
\hline $\mathrm{b}$. & Other (State University, Local Law College, etc) & 0.33 \\
\hline 4. & Hometown & \\
\hline a. & $\begin{array}{l}\text { Large Urban City } \\
\text { (Delhi, Mumbai, Kolkata, Chennai, Bangalore, } \\
\text { Hyderabad) }\end{array}$ & 0.93 \\
\hline $\mathrm{b}$. & Other & 0.07 \\
\hline 5. & High School Education & \\
\hline a. & Medium of Instruction $\sim$ English & 1.00 \\
\hline 6. & Parents' Education & \\
\hline a. & Both Parents completed college & 0.72 \\
\hline b. & One Parent completed college & 0.14 \\
\hline c. & Missing Data & 0.14 \\
\hline 7. & Parents' Occupation & \\
\hline a. & Professional (Legal) & 0.07 \\
\hline b. & Professional (Other) & 0.26 \\
\hline c. & Government & 0.14 \\
\hline d. & Business & 0.14 \\
\hline e. & Managerial / Banking & 0.20 \\
\hline f. & Other / Missing Data & 0.19 \\
\hline 8. & Main Language of Communication & \\
\hline a. & Predominantly English & 0.53 \\
\hline b. & English + Fluent in Other regional language & 0.47 \\
\hline c. & Predominantly Hindi / Other regional Language & 0.00 \\
\hline
\end{tabular}


Notes to Table 2: (a) In 3(b), of the 5 (0.33) respondents who did not attend a national law school, two had earned their legal degree and entered the profession before the set up of these schools in the 1990s. (b) Parents' Occupation in 7 above refers to the fathers' occupation except in cases where the mothers' occupation was reported instead when asked about family background and occupation history. 
Electronic copy available at: https://ssrn.com/abstract=3163567 
Electronic copy available at: https://ssrn.com/abstract=3163567 